\title{
The Impact of Post Colonialism in Amitav Ghosh's Novels-A Post Colonial Perspective
}

\author{
Dr. Venkateswarlu Yesapogu, M.A., M.Phil, PhD. \\ Head, Dept of English, Principal FAC in V.V.\&M Degree College, \\ Ongole, Prakasam D.T., A.P. India \\ Yvghosh.yvghosh@gmail.com
}

\begin{abstract}
Amitav Ghosh meditates upon a core set of issues in all his works, essays and journalism. Each time he does so from a new perspective, and he is especially concerned with contemporary streams of literary criticism. The troubled legacy of colonial knowledge and discourse on formerly colonized societies, peoples, and ideas; the ambivalent relationship to modernity of the so-called developing or 'Third 'world; the formation and reformation of identities in colonial and post-colonial societies is meticulously explained in his fiction. In many of his public pronouncements, Ghosh has disavowed the idea that his work is a representative example of Post colonialism, or that he is a 'post-colonial 'writer. Indeed, he has claimed that he does not really know what the term means. Nevertheless, Ghosh is on friendly terms with many of the critics and theorists who have done much to define the field, and who in turn acknowledge his work as a crucial index of many of the themes, issues, and problematic that constitutes the multi-dimensional nature of the post-colonial predicament today. A critical examination of Amitav Ghosh's writing is thus an opportunity not only to ascertain and evaluate his own predilections and concerns but also to explore the limits and possibilities of post colonialism itself as a critical practice.

Amitav Ghosh reveals areas of colonial oppression that were not much highlighted earlier along with the much talked-about topic of the oppression of the poor by local moneylenders. This article in all its satirical representation critiques on the oppression of colonialism from all the perspective of post colonialism. It reveals the complicit formulation of post national future within the framework of benign masculinity. Ghosh associates undesirable nationalism with feminism. However, for my seminar article presentation I have chosen the title called "The impact of post colonialism in Amitav Ghosh's novels- A Post colonial Perspective" which makes an exploration of the impact of post colonialism in the novels of Ghosh which have faced problems and challenges of contemporary society. However I tried to interpret the nature of this article by observing it from the various cultural aspects of contemporary Indian society.
\end{abstract}

Keywords: post colonialism, criticism, theory, reclamation, hegemony, nationality, dichotomy.

\section{INTRODUCTION}

In the contemporary Indian Literary scenario Amitav Ghosh is the only writer who reflects the truth of Indian reality. $\mathrm{He}$ bears numerous responsibilities in the world of literature. He executes with admirable aplomb as an anthropologist, sociologist, novelist, essayist, travel writer, teacher and slips into global responsibility for establishing peace as an ambassador. He has excelled the global literary standards set by the post colonial and post modern writers like Salman Rushdie, Vikram Seth, Vikram Chandra, Sashi Tharoor, Arundhati Roy etc. He has become the colossal central socio literary figure with a substantial body of work drawing the global attention. He has become the only negotiator to mediate the core social and cultural problems of India and other colonized nations. All his major works have enjoyed immense academic attention across the globe and it has invited and produced a great amount of literary criticism. He has created a wide readership and a strong critical endorsement that reflects the attention of serious academicians and scholars. All the post colonial and post modern predicaments are wrestled to demonstrate a high level of self consciousness which continues interrogate the social, philosophical, cultural issues of the world in all its relevance and freshness. His works have initiated the emergence of critique of nationalism and universalism. His intellectual insights, conceptual, theoretical and textual experiments have engaged and interpreted the complex colonial and post colonial situations. They have established a peculiar paradox of reading and appreciation eloquently responding to the post colonial and post modern issues of evolution and transformation of the world. Making his debut with The Circle of Reason in 1986, he has produced the 
ground breaking novels till today with River of Smoke (2011) that interrogate the history of humanity with discursive discourses. His non fictional writings are equally challenging and stimulating offering philosophical and cultural elucidation on different themes such as fundamentalism, history of the novel, Egyptian culture and literature. Despite this vast amount of creative and critical output surprisingly there is a small amount of critical reception. But his works have become the most favoured areas of scholarly exploration for many of the young scholars and academicians. These explorations have become part of unpublished research that focused exclusively on the relevance of Amitav Ghosh to the contemporary times.

The critical reception on Amitav Ghosh marks a notable divergence of interests between the criticism of Indian subcontinent and the western academy. Criticism from Indian academics mostly concentrated on the novels The Shadow Lines, The Calcutta Chromosome that dealt with the questions of national identity and communalism in the sub continent. There is a note of dissent from the Indian academics as they positioned themselves on the base of traditional Marxist criticism. However, these novels had enormous impact on the much debated post colonial issues of nationalism, identity and the fabricated cultural myths that inflate pseudo nationalism. These texts have become part of university curriculum paving the way for the instant critical response of the students. Besides, there emerged some volume of essays reflecting the overwhelming critical negotiations and interventions breeding other novels The Glass Palace and The Circle of Reason. The Western critical response is firmly based on exploring the experimental and post modern aspects of culture registered in divergence and it is almost unanimously enthusiastic.

The extant criticism on Ghosh's work has exposed significant socio cultural representations. One of the concerns is the representation of gender which has become the subject of much critical debate. The theme of Shadowlines is perceived for the inversion of passive male characters at the expense of active female characters. The novel in all its satirical representation critiques nationalism from the perspective of Gender. It reveals the complicit formulation of post national future within the framework of benign masculinity. Ghosh associates undesirable nationalism with femininity. He repeats some of the national gestures of portraying women as emblematic figures signifying 'culture', 'tradition', 'nation' and authenticity. This is precisely a counter argument for the novel's gender politics. In all his other novels there is relatively little debate about the representation of gender and other issues of sexuality. But as a matter of academic speculation, women have become very significant presences in all his other works. Examining this aspect, James Clifford in the article 'The transit lounge of culture' says that we hear little from women in other novels, but it is only in The Calcutta Chromosome the women figures emerge as central organizing principle ( Times Literary Supplement 3 May, 1991). Mangala as the subaltern leader attempts to subvert the discourse of science articulating an alternate mode of knowledge. The Glass Palace and The Hungry Tide presented detailed and individualized women characters than Ila and grandmother of The Shadowlines.

Political implications in Ghosh's works are another issue of serious concern. His works are perceived as the study of material conditions of post colonial experience. They espouse post modern idealism and elucidate the political realities. A. N. Kaul's essay 'A Reading of Shadow Lines' in The Shadow Lines (1995) aptly justified this perspective. He has argued that the novels of Ghosh the categories of human experience as metaphors of contemporary political realities. John Mee in his article 'The Burthen of the Mystery' praises the anthropological imagination of Ghosh, which has espoused the idea of space and time. Thoroughly examining the divisiveness of nationalism, the works of Ghosh scrupulously examine the enactment of divisive forces of racism, imperialism and class exploitation from the perspective of Indian nationalism. Another critic Robert Dixon in the essay 'Travelling in the West' has argued that In An Antique Land and The Shadow Lines Ghosh has presented an untheorized and utopian belief of humanity. He characterizes Ghosh's writing as an ambivalent tension between liberal humanism and post modernism. Apart from the post modern response to the works of Ghosh, his works are also projected as an abdication of political responsibility or refusal to confront harsh political realities. This perspective is based on the premise that politics requires an active intervention into the affairs of the world. But what is at stake for Ghosh is viable political praxis. In the context of globalization, Ghosh works have accelerated multiple contradictions inherent in post modernity projecting his politics as ambivalent. His politics of ambivalence stand in odd with an activist vision of politics. The significance of Ghosh's politics of ambivalence is in the way it offers us a means of revising what politics might mean in a globalised, post colonial world. 
To a greater extent all, the major works of Ghosh resonate with the preoccupations of contemporary society and culture marshaled under the framework of post modernism. Ghosh exhibits an interest in the nature and philosophy of language, textuality and the discourses in which human perception and experience is invariably shaped. For Ghosh the question of 'identity' is implicated in the representations of 'Self'. To him identity does not stand alone but it is derived from inborn 'essence'. Moreover, it is 'fashioned' by language and representation. From this perception, 'identity' has acquired the status of fiction interrogating the material consequences that influence the actions of humans. The texts of Ghosh interrogating the equivalence of fiction to unreality represent the correlative view that 'identity' is unstable and fluid. The very notion that fiction is untrue is part of the system of knowledge initiated by the intellectual revolution of early modern Europe. As this is deeply implicated in colonial culture, elucidating the intellectual legacy constitutes the central concern of Amitav Ghosh. Negating with the 'meta' or 'grand' narratives of progress of civilization, Ghosh has focused on the fragments of human experience that are excluded from the grand designs of civilization. The generic multiplicity and indeterminacy of his works, splices the contrapuntal formation, which are associated with popular culture.

It is wrong to characterize the works of Ghosh as unproblematically postmodern. His works have showed certain affiliations, but there are other affiliations to the context of his works. So, there is a dire necessity on the part of the reader to execute a peculiar paradox of reading to perceive the novels of Ghosh. They convey a 'sense of place' and 'sense of dislocation' as fictional representations. Our contemporary contexts of our lives are justifiably conditioned by the reactions to dislocations. Ghosh's extraordinary oeuvre portrays a balanced portrayal of warm location and terrifying dislocation. This is predicated on the consciousness of one losing the precious lived sense of place as a catalyst for the emergence of novel. Ghost had evinced a great faith in the evolution of the novel. To him, the novel bears the writers perception and responsibility in a most appropriate manner. The novel according to Ghosh has been universal from its evolution. It creates a space for cross cultural reading and experimental ideas and styles. It is one form of literature founded upon 'a myth of parochiality'. It is from this vantage point, Ghosh takes upon the responsibility of using history as a tool for fictional representation.

The imagination of Ghosh is a product of specific histories of the subcontinent and necessarily diasporic and post colonial. He unveils himself as a world traveler and reveals the identity of every place with subtle presentations. Cutting across autobiographical resonances, Ghosh permeates academic antecedents-history, sociology and anthropology. With all his historical research pursuits, $\mathrm{He}$ is concerned with Indian/South Asian diaspora in different regions of the world. He is intrigued by the inherent fracturedness of diasporic identity. Analysing the space with reference to history, he travels between cultures and lands with the power of imagination. He retrieves the history of India, Bangladesh, England, Egypt, Burma, Malaya is his novels. Reiterating the journey of imagination of the West Indian novelists such as Wilson Harris, Derek Walcott, Ghosh reinvents the ways of subverting the colonial injustices. He interrogates the burden of colonial past that weighs heavily on migrant post colonial generation. In all honesty, he churns out a glimpse of 'final redemptive mystery'. The retrieval of imagination with the objective of subverting the grand colonial history is employed meticulously by Ghosh in his works.

Ghosh makes an intellectual exploration into the history of marginalized and the contexts of nationalism, internationalism, migrancy, violence and communalism. He constantly looks for the ways to render history into fiction and often posits fiction against history. Exploring the human predicament, he finds the individuals and characters asserting and liberating themselves from the burden of history. His sensibility of unveiling the nuances of history, sociology and culture makes him distinctive apart from the bunch of Indian novelists. The Diaspora and displacement are the keys to understand the thematic concerns of Ghosh. They direct us to explore the contemporary perplexities in hyphenated identities. The dilemmas of diaspora engendered in the margins of history are fore grounded in Ghosh's fiction. The historical research and exploration becomes secondary to some extent. Arun P. Mukherjee in Oppositional Aesthetics: Readings from a Hyphenated Space is concerned with reading the novels of Ghosh as oppositional to the dominant literary and cultural ideologies of Euro America. But Ghosh's intellectual exploration of the major and marginalized cultures is seen as representation of aesthetics. However, if one accepts the moot point that fiction is a representative of human history, one can trace the genesis of humane historian. Ghosh as a humane historian travels between cultures and negotiates for a 'third space' in social studies. In the 
contemporary clash of binaries of nationalism, globalization ushers in the erasure of culture and articulates the absence of culture emphatically. So, when the cultural interaction is confined to exchanges between national cultures, the inhabitants of the third space oscillate between the dominant cultures. Nikos Papastergiadis in The Turbulence of Migration (2000) says that Ghosh's fiction negotiates between two lands divided by space and time and attempts to redefine the nuanced understanding of the past.

\section{The Impact of Post Colonialism in Amitav Ghosh's Oeuvre-A Critical Perspective}

Out of six novels, all the novels are quintessential postcolonial novels. Post-colonial criticism has become academically compelling criticism. Post-colonial theory explores the textual criticism of postcolonial literatures. Frantz Fanon's Black Skin White masks (1952) and Wretched of the Earth (1967) and Edward said's Orientalism (1978) and Culture \& Imperialism (1993) are considered to be the promulgators of Post-colonial criticism. These seminal works have strongly recommended the reclamation of the past of colonized nations only to subvert the hegemony of the colonial nations. Bill Ashcroft, Gareth Griffith \& Helen Tiffin's The Empire Writes Back (1989) with a broader cultural circumscription of all the colonized nations provided a strong base for post-colonial criticism. This is further continued and consolidated by Gayathri Spivak Chakravarthy In Other Worlds: Essays_in cultural Politics (1988), Homi K.Babha's Nation and Narration (1990) and Location of Culture (1994). These works have interrogated the identities of colonialism. The concocted colonial identities of Nation, Nationality, and National representations are interrogated and the male cantered perspectives are demolished. All the six novels that examined for the article engage in the critical negotiation of past history by Amitav Ghosh. The presentation of past history is with ambiguity. The ambiguous nature of past history has revealed the dichotomy of the past history as glorious and inglorious which interface fiction. The usable past becomes the glorious past and the unusable past becomes the inglorious past.

All these novels need to be examined in understanding the dichotomy of 'Colonialism'. It needs to be examined in relaxation to 'internal colonialism' and external colonialism. India is a country, which suffered from 'Internal colonialism' since the beginning of its civilization. It continues to suffer from 'Internal colonialism' even after the demise of colonial period. Women in India are the victims of 'Internal colonialism' as well as the external colonialism. The victimization of women in 'Internal colonialism' went on unabatedly in silent acceptance. Post-colonial criticism has also revealed and questioned the patriarchal mechanism in victimizing women by creating the passive images of contemporary women. The protagonists in all these six novels are the victims of internal colonialism.

It is only with post-Colonial criticism the issues of confrontation dealt by these works can be deciphered. The protagonists in all these novels in the process of liberating and defining themselves tried to establish alternative roles. The protagonist in "Sea Of Poppies" (2008) is confronted by the horrifying future carrying the burden of innocent past life in India. There is a juxtaposition of the life spent in India and the life being lived in the northern Bihar. In the process of living in northern Bihar, she obliterates the conventional images of motherhood. 'Sea of Poppies' of Ghosh perfectly presents the juxtaposition between the pre-colonial India and post-colonial India. The very transformation of the protagonist from a submissive domestic life is rendered in all its appreciation. This obviously presents the radicalization in the very construction of social identities and positions. The social maturation in the character provides a space in which the pre-colonial constructions of Nation and Nationality are interrogated.

In The Imam and the Indian and as well as in In an Antique Land of Ghosh, we see the exploration of history. Ghosh subscribes to the values of their own culture. The emotions and passions are linked with their past. These people along with the people from the shared past history from "Composite Communities". In The Glass Palace, Ghosh showed the search for her uncle Dinu, Raj Kumar's granddaughter. She seeks to reconstitute her grandfather's history and also the history of Aung San Suu Kyi through Dinu. She visits Burma and peeps into past of her uncle Dinu.

Jaya comes to acknowledge the girlhood and the typical motherhood, looking for her son's safety after the sudden demise of her husband in an accident. Experiencing 'others' the children of migrants bear the burden of carrying the past. We are shown through Jaya's retrospection and scanned Psyche that these children carry with them the past history of "origin" of their parents and grandparents and 
are treated as a secondary citizen even though they are born and brought up here. Jaya feels shattered when she goes on to search for her uncle Dinu from corner to corner in Burma, when she meets him at once shading their faces "green with broken eye shadow", to different ideas for collecting memories with each other. She is called by name, are you Dinu? I am your niece, daughter of your own brother Neel granddaughter of Rajkumar and Dolly your parents. Thus, Jaya faces an identity crisis as her identity is defined in terms of the past history of her parents and grandparents.

In the novel The Glass Palace along with the discussion of colonial rulers and their subjects Queen Supayalath carries on a discourse that unruly depicts 'cruel politics'. If the Indian princes constitute the other in the power game between the British and themselves, it is Queen Supayalath who is symbolic of woman as the other in human relationships. As living in Burma Jaya is brought into light by the skills of her research. The journey of Jaya's research from her childhood to maturity is full of enriching experiences.

Post-colonial criticism has initiated significant changes in the discourse of nationalism of colonized countries. It offered genuine criticism of the evolution of the feeling on Nationalism. It has projected the idea that Nationalism has emerged to check the growth of capitalism and Industrialization. Ernest Gellner in Nations and Nationalism (1983) observed that Nations are not inscribed into the nature of things. Nations are like planned things. They are like constructed buildings. The very idea of the nation is considered to be a myth. Benedict Anderson in Imagined Communities: Reflections on the Origins and_Spread of Nationalism (1983) argues that nations are imagined political communities. The essential symbols like national flag, national bird, national animal, national anthem that stood for the significance of nationalism are all prepared cultural artifacts by the so-called pre independent national leaders.

Post-colonial criticism has also revealed the very cultural strategy involved in identifying the land of the nation with the body of the women. This is intentionally schemed to incite the sentiments of the common people. The occupation of their land is projected as the molestation on the dignity of their woman. The colonial occupation is interpreted on these lines only to invite the participation of the common people in the so-called struggle for independence. It is pertinent to observe that in the larger struggle for Independence the very crucial aspect of the Independence of women is excluded. It is from this perspective Partha Chatterjee in his influential book Nationalist thought and colonial world (1986) considers nationalism as a derivative discourse. He considers that idea of Nationalism is in complicit with the elite sections of the society. Post-colonial criticism has also revealed how the nature and subjectivity of women's life is exploited by the national leaders in their struggle for freedom. Particularly Mahatma Gandhi is understood to have exploited the subjectivity of Indian womanhood in his methods of staging hunger strike, non-cooperation and non-violent demonstrations. Gandhi has exactly employed the nature and psyche of Indian womanhood. Post-colonial criticism has revealed the ways in which the subjectivity of Indian womanhood is exploited like Deeti in Sea of Poppies (2008) only to further undermine the social positions of Indian women and Gandhi is no exception in the scheme of Indian patriarchy.

The women protagonists in these novels are the representatives of post-colonial critique of Indian society. Deeti, Munia, and Paulette in Sea of Poppies and Dolly and Uma in The Glass Palace are the apt representatives of post-colonial critical spirit. The life related to the mother and daughter weaves between the pre-independent and post Independent India presenting the glimpses of usable past and unusable past. The holocaust during the times of partitions strongly signifies the inglorious past.

The post-independence situation which Jaya constructs her life to the level of challenging the intellectual hegemony of researcher is nothing but the obliteration of all the imposed social roles. The self-affirmation that Deeti exhibits reveals the true colour of colonial intrigues that multiplied gender inequality and discrimination.

Ghosh's The Hungry Tide is also a quintessential post-colonial novel. Moreover, the theme of Sea of Poppies perfectly suits the post-colonial propositions as it presents the position of Indian women in pre-Independent and post-Independent situation of India. The colonial and the social displacement of Indian nobility and the kingly class in Dancing in Cambodia, at Large in Burma is well crafted within the post-colonial critical framework. One of the protagonists in The Glass Palace Jaya displays the required wisdom to understand British colonialism better than the other male characters. In the male dominated culture of The Hungry Tide and Sea of Poppies Piya and Deeti, win the legitimacy to inherit the rule purely on their own. In this process, they overcome the conventional hurdles of 
Kabutri, the daughter of Deeti and Tutel, son of Fokir considered as the natural heir to Fokir and heiress to Deeti. Princess Soumphady becomes the true representative of Indian Culture by ably implementing the dancing lessons and principles of ruling the nation after the King Sisowath. Enacting the conventional role of wife and as well as mother, Deeti upholds the dignity of the Indian culture by disallowing the cunningness, cruelty and perverted intrigues of Chandan Singh who is a colonial representative. She also realizes that the ultimate legitimacy to rule the nation rests with the 'people' and obliterates the patriarchal authority. The way Deeti registers protagonism is the way, which unravels the intrigues of conventional images and symbols meant for manufacturing the socalled pseudo nationalism. Post-colonial criticism of the nationalism of colonized nations finds sagacity in the very interpretation of Amitav Ghosh's Sea of Poppies.

Colonialism had condemned millions to a life of subservience and dispossession. At this juncture, the anti-colonial nationalisms promised a new dawn of independence and political self-determination for colonized people. In the twentieth Century, the myth of nation has proved highly potent and productive during several struggles against colonial rule. Under the development of created constructed myths, the nation became highly mobilized as a powerful symbol, which anti-colonial movements used to organize against colonial rule.

The colonial rule has dismantled the political structures of many nations and the worst hits were the countries of the South Asian region. Many countries had become the British colonies. In the South Asian regions, it was India, Burma and Malaysia that suffered from the colonial oppression. These countries are known for their rich cultural heritage, richest natural resources and abundant wealth.

The British intrusion into these lands in the name of business exemplified the strategy of colonialism. However, the intrusion into the serene lands had no effect on the part of the commoner. In fact, the commoner thought that the colonial rule came as a liberating agency from that of the monarchical rule, which they are facing. Especially in Burma, the commoner had developed an aversion towards their King Thebaw and the Queen Supayalat. The opening chapters of The Glass_Palace reveal the aversion of the Burmese crowd towards their superior authority. "Through all the years of the Queen's reign the townsfolk had hated her for her cruelty, feared her for her ruthlessness and courage" (34). The looting of the King's palace by the Burmese Public clearly shows their aversion. When the British had seized Thebaw from power, it was the public who has to lend the support through difficult phase of time. Instead of that, they turned against him and they indulged in looting their own King's Palace. The King has failed as a good ruler. That was the reason why they considered the British as the liberating agency. It is here the question of state comes into light. In the countries, which are governed by the state, people develop a sense of looking after the well-being of each and every individual. This tendency provides source of revenue for its people and sets the standards of living. By doing so, the state gains a perfect control over its people and the social hierarchy runs with perfection. But if the state fails in providing livelihood and other necessities for its people, it loses control over them and hierarchy gets dissolved.

The British intrusion into Burma had changed everything. Thebaw lost his power and so the Queen. Their own people had looted their palace. It was a huge humiliation for the royal couple. They never noticed the growing unrest in the public of their rule. When the British came into the land the crowd seized the opportunity to sneak into the palace. Until the British arrival, no commoner in the country had dared to enter into the palace. They knew that it would result in summary execution. But now everything has changed. The King and the Queen were thrown out of power. The Queen's reaction when she saw the mob inside their palace shows her impotence.

The King and the Queen along with trusted servants were shabbily been discarded from the country to a remote coastal village in India. No one in the country felt sorry for their eviction from the country. It was the colonial rulers ploy in exiling the King's family from their own land in order to erase them completely from the public memories. Earlier, the Indian Mughal King, Bahadur Shah Zafar too was exiled in the same manner. The colonial rulers exiled him to Rangoon from India.

The colonial rule has a huge affect on the members of the elite group in Burma as well as in India. Prior to the British occupation, they had a strong food hold in the country. But now they have lost their grip on the soil. In order to raise their voice against the colonial rule their number is limited and they needed the support of all the people. Until then, they never considered the other people and the social hierarchy had created a great abyss between them and the subaltern people. "Many once colonized nations have struggled with the internal differences that threaten the production of national 
unity" (McLeod: 2000). The term 'Subaltern' is used to signify the many different people who did not comprise the colonial elite. The colonial elite includes, the lesser rural gentry, impoverished landlords, rich peasants and the upper middle class peasants.

The production of a unified imaginary community became nationalism's greatest strength. The nationalist elite claims that their 'modern' attitudes are coterminous which 'popular consciousness' and enjoy the support of the people, deemed to be a unified singular entity sharing the same political aims. The myth of the nation functions as a valuable resource in uniting people to raise their voice against the pangs of colonialism. It worked against the differences created out of gender, racial, religious, dialectical and cultural differences.

It is obvious that the British occupied Burma and India resulted in creating a sense of Nationalism. Prior to the British arrival, there were differences in people. However, the arrival of the British has changed everything. The internal differences were set aside and the idea of nation had been created. In Paul Gilroy's Words, opines:

...through elaborate Cultural, ideological and political processes which culminate in feeling of connectedness to the other national subjects and in the idea of a National interest that transcends the supposedly petty divisions of class, region, dialect or caste' (1993:49)

Ghosh's Dancing in Cambodia, At Large in Burma is the third essay in the book, "At Large in Burma is another study of the 'self' of Aung San Suu Kyi. She is reflected on the author's three meetings. The way Suu Kyi has constructed her 'self', fashioning herself to the circumstances of Kings of Burma and the British is similar to the life of Queen Elizabeth who made her 'self' as the ultimate image of England. Suu Kyi learns the required intrigues to rule her nation almost undaunted by the destruction of her family life. Imbibing the machivellian spirit, she disallows the dominace of British, as well as her father's opponents, by conquering the barrier of gender. Suu Kyi's personal history becomes the history of her nation.

All the novels of Amitav Ghosh have cross-cultural interactions. The definition of culture itself is divided in its significance, since the term is open to a variety of interpretations. (Raymond Williams Culture and Society, 1780-1950.254). But as Gerald Graff and Burce Robbins observes: "the conflict between culture in the anthropological sense and culture in the normative sense leads to a thrifts way of using the term, one that refers neither to a people's organic way of life nor to the normative values preached by leading intellectuals but to a battle ground of social conflicts and contradictions" (255). (Gerald Graff and Burce Robbins Cultural Criticism Redrawing the Boundaries, ed Stephen Greenblatt and Giles Gunn. 1996:421).

It is this lived experience of cultures that from the "textual sites" of Amitav Ghosh's The Imam and the Indian. In his work, he foregrounds the experiences of a colonial domination forced to confront her marginalization within his own (Indian) culture, while attempting to forge an identity with in alien (American, England) culture, both of which are entrenched in patriarchal ideology delineating Ghosh's attempt at negotiating the cultural and ideological divides. Amitav Ghosh provides for the contradictory interactions of culture, ideology, and identity on behalf of post colonialism.

Amitav Ghosh's The Imam and the Indian also portrays multicultural theme. The characters are caught in the web of multicultural entanglements. Living with objectivity and compassion these immigrant characters mostly struggle for identity and commitment to life in the multicultural milieu of Afganistan, Bengal, Khabul, Burma and the beyond. We find most of the first generation migrants facing cultural dilemma and trying their best to retain cultural identity and cultural practices in their beliefs and values. John McLeod in Beginning Post-colonialism observes, "these beliefs, traditions, customs, and values along with their "possessions and belongings" are carried by migrants with them when they arrive in "new places". The clash between their values and beliefs of their own culture and concept of "home" and their beliefs baffle in old Egypt when Ghosh went for research. However, among the second generation these emotional links are loosened as we see in the life styles of old Egypt's villagers. The natural school of criticism that comes to the fore to analyse the themes of Amitav Ghosh's novels are under colonial literary criticism. It has circumscribed the contemporary Indian fiction.

John McLeod in Beginning Post-colonialism-(2000) says that first world Feminism is confined to Europe, America and Australia. Second World Feminism is confined to Soviet Union and communist allies Feminism. Third World Feminism is confined to the Africa and under developed South Asian 
Countries. Though this is an unhappy generalization, it has proved the limitations of the first and former classifications of Feminism. In order to bring in the legitimacy to the classifications in Feminism, Kirsten Holst Peterson and Anna Rutherford have introduced the concept of 'double colonization' in A Double Colonization' Colonial and Post Colonial Women's Writing(1986). This refers to the ways in which women have experienced the oppression of colonialism.

The Feminist writers tried to stamp their authority in a colonial dominated environment as best as it is possible to them. It was a very difficult path, as the Indians had to break through years of colonial dominance, taboos and beliefs that had heavily impregnated the society. In addition, critics argued that colonialism operated very differently for women and for men. This was so because women were subjected to both general discrimination as colonial subjects and specific discrimination as women addressed as 'double colonization.'

It is from these perceptions one should view the contribution of women writers of the nineties like Anita Desai, Shashi Deshpande, Gita Mehta, Gita Hariharan, Bharati Mukherjee, Uma Vasudev and Arundhati Roy. Undoubtedly, it is understood that they have perceived a good job in exposing the fallacies of the male -dominated society and letting the public beware of the various atrocities heaped upon women who dared to cross the various rigid boundaries that were laid on them by society. The novels of Amitav Ghosh like The Glass Palace, Dancing in Combodia at Large in Burma, In an Antique Land, The_Hungry Tide and Sea of Poppies 2008 have beyond a shadow of doubt, been successful in opening the reader's mind and heart to view the life of a woman from a women's point of view.

The debate in several colonized societies over the deleterious effects of gender or colonial oppression on women's lives continues to hold its significance in the analysis of the society. Feminism, like post Colonialism, is concerned with the ways to which representation and language were crucial in order to identify the formation and construction of subjectivity. Both for the patriarchal as well as the matriarchal community, language was crucial in order to identify formation and for the construction of subjectivity. Language subverts patriarchal power and brings more authentic forms for negotiating gender equality.

All these novels of Amitav Ghosh like Dancing in Cambodia at_Large in Burma, In an Antique Land, The Imam and the Indian, The Glace Palace, The Hungry Tide and Sea of Poppies subscribe to the aspects of narratology and carry the innovative techniques of narration. The themes of all these novels are under Post-colonialism in between the past and present with history interface contemporary issues and methods of narration.

\section{CONClusion}

To understand the significance of Amitav Ghosh, one should travel beyond the paradigms of Commonwealth literatures. In fact, the classification of Commonwealth has become conventional on the lines of mainstream literatures. One should sincerely acknowledge the contribution of Amitav Ghosh in saving the literature of Commonwealth countries from becoming pedantic and pedagogic. Ghosh is responsible for bringing in the continental themes such as immigration, revisioning history, anthropology, sociology and the disciplines of knowledge. It is with the scholarly intervention of Ghosh, there has been a great change in the very perception of the disciplines that formulate and influence the evolution of the society. He has diverted the attention of the literature of the third world, from being occupied with problems of discrimination inflated by colonialism. As a result, there is a shift from African, Caribbean, Latin American, South African literatures to South Asian literatures. It is only with the scholarly excavation of Ghosh, the entire history of Colonial history of South Asia is being redrawn and reassessed from the socio literary telescopic reflection of Ghosh.

Ghosh has become universally popular for interlocking and striking stories. Underscoring a sense of vocation, he brings in sociological, anthropological academic excellence for his narrations. His narrations show an evidence of careful and scholarly observation of the cultures with an implied deep philosophical investigation regarding the sagacity of humanity. He takes immense delight in creating and shaping the characters with all stylistic devices and extraneous academic investigation. Ghosh has revolutionized the faculty of imagination. He has stretched the horizons of imagination to the farthest extent even beyond the ability of imagination. His imaginative exploration has almost redrawn the geography of South Asian region. 
Assisted by anthropological investigation, Ghosh tries his best in retrieving the Colonial history of South Asia with the objective of rectifying the imbalances in the cultural formation and evolution of the society. As a historian, Ghosh tries to recuperate the remnants of past history, but fails to provide chronological accuracy almost on the lines of West Indian and Latin American writers. The dire necessity to provide a chronological shape to the South Asian history makes him to depend on imagination exploration. This has made him a renowned writer for re-membering and piecing together the disjointed pieces. As his works are pre eminently immersed in history, there is a sudden surge in the critical reception showered on him. Critics have extracted historical, political, anthropological, sociological and cultural nuances from his writings and his personal opinions and interviews have become immeasurable sources for perfectly interpreting the global culture.

In one of the interviews to Mary Gray Davidson, the producer of American radio programme, Ghosh has refused to identify himself with the 'common ground'. In another interview with Calcuttaweb. He wished for protecting the artistic freedom of all writers with a sense of individualty. Giving his opinion with Michelle Caswell, he expressed his immense faith in the ability of the novel as a Meta form that transcends the boundaries between history, anthropology and journalism. Justifying his choice of becoming a novelist, he opined that his fiction is about the evolution of making of unmaking of the communities. But despite his emphasis on the remaking of communities, he focus on the individuals has become the locus for change. He firmly believed that this has made him to be occupied with the issues of marginality, exclusion and the process of 'othering'. When post colonial perception has claimed the closure of the battling on the process of 'Othering', Ghosh has made the war serious and almost fresh providing space for debating more crucial issues that questioned the foundation of South Asian societies.

The diasporic imagination of Amitav Ghosh has helped him in wrestling with the aspects of multiculturalism and the yokes of violence that marred distant identities. Ghosh's diasporic imagination has become inevitable in understanding history and legitimizing imaginative rendering of South Asian history. His impressive oeuvre has triggered reconciliation between literary imagination and formidable political consciousness. This has become a defensive mechanism in protecting the Indian writers in English that they are politically irresponsible. So, the burden of the Indian writer is further weighed by the responsibility of solving the postcolonial contexts.

The attempt of this article is to bring together multiple interpretations and elucidations of Ghosh's best-known works, as the response of literary criticism is proliferating across the world. Over the last one year, there are umpteen critical perspectives gushing out like a volcano which have become inevitable part of academic syllabus in every institution of higher research and learning. For obvious reasons literature needs to percolate and foment our consciousness and hence are the provocative readings of Ghosh's fiction. In this direction, the article overcomes the limitations of critical perspectives and offers a scrupulous understanding of Ghosh to the best possible extent.

\section{REFERENCES}

\section{Primary Sources}

Ghosh, Amitav: Dancing in Cambodia, At Large in Burma.

New Delhi: Ravi Dayal, 1998. Print.

..... In an Antique Land. New Delhi: Ravi Dayal, 1992. Print.

...... The Glass Palace. New Delhi: Ravi Dayal. 2000. Print.

........The Imam and the Indian. Prose Pieces. New Delhi:

Ravi Dayal/Permanent Black, 2002. Print.

.......The Hungry Tide. New Delhi: Ravi Dayal, 2004. Print.

........Sea of Poppies. Ravi Dayal, Penguin Viking, 2008. Print

\section{Secondary Sources}

\section{Books, Articles and Reviews}

Adhikari, Madhumalati. 'The Calcutta Chromosome: A post-Colonial Novel' in Indira Bhatt and Indira Nityanandam (eds.) The Fiction of Amitav Ghosh: 177-83. Print.

Agarwalla, Shyam S. 'Magic Realism in Amitav Ghosh's The Circle of Reason' in Amar Nath Prasad (ed.) Studies in Indian English Fiction 2001. Print. 
Almond, Ian. 'Post-Colonial Melancholy: An Examination of Sadness in Amitav Ghosh's The Shadow Lines'. Orbis Litterarum. 59.2 (2004): 99-99. Print.

Amin, Armina. 'Going Away/Coming Home: Points of Fixity or Th-Shadow Lines' in Indira Bhatt and Indira Nityanandam (eds.) The Fiction of Amitav Ghosh: 50-56. Print.

Anderson, Benedict. Imagined Communities: Reflections on the Origins and Spread of Nationalism. London: Verso. 1983. Print.

Andersen, Elizabeth J. 'Excavating the Remains of Empire: War and Postimperial Trauma in the Twentieth-Century Novel'. Diss., University of New Hampshire, 2002. Print.

Anon. 'Amitav Ghosh 1956: Indian Novelist, essayist and non-fiction writer; Contemporary Literary Criticism. 153 (2002): 81-132. Print.

Ashcroft, Bill, Gareth Griffiths and Helen Tiffin's The Empire Writes- Back 1989, eds. Key concepts in Post-Colonian. Routledge, 1998. Print.

Aslami, Zarene. 'Questions of Authority. The Story of Three-Generations Living in the Shadow of Empire: Review of The- Glass Palace'. Chicago Tribune Books. 1154. 35 (4 February 2001): 3, 7. Print.

Barry, Peter. Biginning Theory: An introduction to literary and Cultural theory. Manchester and New York: Manchester University Press. 1995. Print.

Basu, Srimati. 'Refracted Light: Teaching In An Antique Land: in Brinda Bose (ed.) Amitav Ghosh: 204-212. 2003. Print.

Belliappa, K.C. “Amitav Ghosh's In an Antique Land: An Excursion into Time Past and Time Present," The Postmodern Indian English Novel, ed. Viney Kirpal. Delhi: Allied, 1996. Print.

Benita, Parry. Problems in Current Theories of Colonial- theories. Oxford Literatury review of 1987. Print.

Bhabha, Homi. K. Nation and Narration and The location of culture. New York: Routledge. 1990, 1994. 5 March 2010. Print.

Bhatt, Indira and Indira Nityanandam. (eds.) The fiction of Amitav Ghosh New Delhi: Creative Books, 2001. Print.

Boehemer, Ellike. Colonial and Postcolonial literature: My grant Metaphores. Londaon: Oxford Press, 1995. Print.

'Book Review: In an Antique Land by Amitav Ghosh'. 2000. <http://www.metimes.com/2k/issue 2000-49/cluent/book- review.>

Bose, Brinda. (ed.) Amitav Ghosh: Critical Perspectives. Delhi: Pencraft International, 2003.Print.

..... 'Footnoting History: The Diasporic Imagination of Amitav Ghosh' in Makarand Paranjape (ed) In Diaspora: 235-45.

Budhos, Marina. 'Questions of Allegiance:Review of The Glass Palace'. Los Angeles Times Book Review.(11February 2001): 5. Print.

Chakravorty, Gayatri Spivak. In Other Worlds: Essays in Cultural Politics. London: Routledge, 1988. Print.

Chambers, Claire. The Relationship between Knowledge and Power in the Work of Amitav Ghosh Leeds, 2003. Print.

Champeon, Kenneth. 'The Last Queen of Burma' The Iriwaddy. I July< http://www.irrawaddy.org. > 2003. Print.

Chatterjee, P. The National and its Fragments: Colonial and Post-Colonial histories. Princeton: Princeton University Press 1993. Print. 'Nationalist thought and colonial world: London Press 1986. Print.

Chatterjee, Roma. 'Between Myth and Ethnography: An Anthropology Reading of In An Antique Land; in Brinda Bose (ed.) Amitav Ghosh: 91-102.

Chew, Shirley. 'Texts and Worlds in Amitav Ghosh's In An Antique Land' in Maureen Bell et al (eds.) Reconstructing the Book: 197-209. Reprinted in 'Texts and Worlds in In An Antique Land' in Brinda Bose (ed.) Amitav Ghosh: 103-116.

Davis, Racio G. 'To Dwell in Travel: Historical Ironies in Amtiav Ghosh's In an Antique Land' in Gerhard Stilz (ed.) Missions of Interdependence: 239-46. 
Dayal, Samir. 'The Emergence of the Fragile Subject: Amitav Ghosh's In an Antique Land' in Monika Fludernik (ed.) Hybridity and Postcolonialism. ZAA Studies: Language, Literature, and Culture. I. Tubingen, Germany: Staufenburg, 1998.8: 103-33. Print.

'A Choice of Histories: Ghosh vs. Hegel in In an Antique- Land' in Tabish Khair (ed.) Amitav Ghosh: 56-72.

.. 'In An Antique Land: A View' in R.K. Dhawan (ed.) The Novels of Amitav Ghosh: 192-93.

Dhawan, R.K. (ed.) The Novels of Amitav Ghosh New Delhi: Prestige, 1999. and 2010. Print.

Dixon, Robert. 'Travelling in the west: The Writing of Amitav Ghosh'. The Journal of Commonwealth Literature. 31.1 (1996):3-24. Print.

Dutta, P.K. "Thematic and Structural Concerns" on Ghosh's The Glass Palace. 1990: 67. Print.

Fanon, Frantz's Black Skin White Masks (1952) and Wretched of the Earth. Scottish Academic Press, 1967. Print.

'Footnoting History; The Diasporic Imagination of Amitav Ghosh'in Markar and Paranjape(ed) In Diaspora: 235-45.

Ganguly, Keya. 'Something Like a Snake: Pedagogy and Postcolonial- Literature'. College Literature.19-20.3-1(1992 Oct-1993 Feb): 185-90. Print.

Geertz, Clifford. 'Review of Amitav Ghosh's In an Antique Land'. The Australian. (25 August 1993): 30. Print.

... 'A Passage to India: Amitav Ghosh's In an Antique Land'. New Republic. 209. 8-9 (1993): 3841. Print.

Gellner, Ernest. In Nations and Nationalism London Press: 1983. Print.

Gera, Anjali. 'Des Kothay? Amitav Ghosh Tells Old Wives Tales' in Tabish Khair (ed.) Amitav Ghosh: 109-127.

Geertz, Clifford. 'Review of Amitav Ghosh's In Antique Land'. The Australian. (25 August 1993): 30. Print.

Ghose, Sagarika. 'The Shadow Lines: Review of The Hungry Tide'. The Indian Express. 27 June 2004.

Ghosh, Amitav: An Introduction; Contemporary Indian Writers in English series; Foundation Books, New Delhi: 2005, 131-32. Print.

Ghosh, Amitav. The Circle of Reason. New Delhi: Ravi Dayal, 1986 Print.

.The Shadow Lines. New Delhi: Ravi Dayal, 1988. Print.

The Calcutta Chromosome. New Delhi: Ravi Dayal, 1996. Print.

Countdown. New Delhi: Ravi Dayal, 1999. Print.

Gibert, Harriet. 'Ghosh's Words of Change'. 27 July 2000.

Gupta, Nilanjana. 'In an Antique Land: A Counter-Narrative of Coloniality' in R.K.Dhawan (ed.) The Novels of Amitav Ghosh: 194-201.

Hayward, Helen. 'Once a Golden Land: Review of The Glass Palace'. Times Literary Supplement. 50-76 (14 July 2000): 21

Hiatt, Shobha. 'Review of the The Calcutta Chromosome' 1998.

Hickling, Alfred. 'Islands in the Stream: Review of The Hungry Tide'. The Guardian Weekly. 19 June 2004.

Howe, Stepen. 'Sea Changes: Review of In An Antique Land'. New statesman and Society. 25.222 (1992): 48-49. Print.

Hussain, Shawkar. 'Post-Colonial Angst in Amitav Ghosh's The Shadow Lines' in Niaz Zaman et al (eds.) Colonial and Post-Colonial Encounters Dhaka:Manohar Publications, 1999. Print.

'In an Antique Land: A Critical Study' in R.K.Dhawan (ed.) The Novels of Amitav Ghosh: 164-77.

Iyer, Pico. 'The Nile of Time: Review of In an Antique Land'.Los Angeles Times Book Review. (11 April 1993): 2, 11. Print.

.... 'The Road from Mandalay: Review of The Glass Palace' New York Review of Books 48. 4 (2001): 28-31. Print.

James, Louis and Jan Shepherd. 'Shadow Lines: Cross Cultural Perspectives in the Fiction of Amitav Ghosh'. Common Wealth Essays and Studies.14. 1 (1991):28-32.Print. 
Joshi, Priya. 'A Bridge over Troubled Water: British Popular Fiction And the Development of the Novel in India'. Diss, Columbia University, 1995. Print.

Kamath, Rekha. 'Memory and Discourse: On Amitav Ghosh'sIn an Antique Land' in Thomas Wagenbaur (ed.) The Poetics of Memory. Stauffendburg Colloquium. 45, Germany: Stauffenburg, 1998: 205-13. Print.

Kapadia, Novy. (Ed.) Amitav Ghosh's The Shadow Lines: Critical Perspectives New Delhi: Prestige, 2001.Print.

.... 'The Politics of Isolation and Resurgence in Dancing in Cambodia, At Large in Burma' in R.K.Dhawan (ed.) The Novels of Amitav Ghosh: 282-94. 2001. Print.

Kesavan, Mukul.. "The Written World' Review of The Imam and the Indian". The Hindu Literary Review. 2002-1.Print.

Khair, Tabish. (ed.) Amitav Ghosh: A Critical companion.Delhi: Permanent Black, 2003. Print.

..... 'The Example of Amitav Ghosh: (Re) Establishing Connections'. Babu Fictions: Alienation in Contemporary Indian English Novels New Delhi: Oxford UP, 1995: 302-32. Print.

Khan, A.G. 'Book Review: In an Antique Land by Amitav Ghosh' 2000. <http://www.metimes.com/ 2K/issue2000-49/cultent/book_review.htm

Kich, Martin. 'Mosquito Bites and Computer Bytes: Amitav Ghosh's The Calcutta Chromosome'. Notes on Contemporary Literature.30.4 (2000): 9-12. Print.

King, Bruce. 'In An Antique Land'. World Literature Today. 68.2 (1994): 430. Print.

.Kiteley, Brian. 'Trapped by Language: On Amitav Ghosh's In An Antique Land'. 2000. http://www.du.edu/ bkiteley/ ghoshtalk.html

Kothari, Reena. 'A Traveller's Tale: In an Atique Land' in Indira Bhatt and Indira Natyanandanam (eds.) The Fiction of Amitav Ghosh: 107-111.

Kumar, Akshaya. 'Prose Behind and Beyond the Shadow Lines: Review of The Imam and the Indian'. The Tribune of India.20 April

Lal, Vinay. 'A Meditation on History: Review Article on AmitavGhosh's In an Antique Land'. 1993http://www.sscnet.ucla.edu/southasia/History/British/Amitav Ghosh.html

Mahanta, Banibrata, Somdev Banik and Namrata Rathore. 'Writing is Like Music: Interview with Amitav Ghosh',The Hindu.21 May 2000. Print.

Majeed, Javed. 'Amitav Ghosh's In An Antique Land: The Ethnographer-Historian and the Limits of Irony'. The Journal of Commonwealth Literature. 30. 2 (1995): 45-55. Print.

Mc Leod, John. Beginning Post-Colonialism: Manchester: Manachester University Press 2000. Print.

Mishra, Pankaj. 'Review of The Glass Palace'. New York Times Book Review 106.6 (2001):7. Print.

Mongia, Padmini. 'Medieval Travel in Postcolonial Tmies: Amitav Ghosh's In Antique Land' in Tabish Khair (ed.) AmitavGhosh: 73-89.

Morkal, Rakhee. "In Time of Breaking of Nations'. The Glass Palace as Postcolonial Narrative" in Brinda Bose (ed.) Amitav Ghosh: 139-54.

...... 'In Antique Lands, ' Indian Review of Books, 7:10 (1998): 6-8. Print.

..... 'Dancing in Cambodia, At Large in Burma'. India Star Review of Books. 1998. http://www. indiastar.com/mukherjee1.html

Mukherjee, M.. 'Of Love, War and Peace,' review of The GlassPalace, Indian Review of books, Vol. 10, No.1. 2000. Print.

Nair, Rukmini Bhaya. 'The Road from Mandalay: Reflections on Amitav Ghosh's The Glass Palace' in Tabish Khair (ed.) Amitav Ghosh: 162-74.

Pandit, Nirzari. 'Subversion of History in/ through Fiction: A Study ofThe Shadow Lines and In an Antique Land' in Indira Bhatt and Indira Nityanandam (eds.) The Fiction of Amitav Ghosh: 13341.

Peterson, Kirsten Holst. And Anna Rutherford: 'Double colonization' in A Double Colonization, Colonial and Post-Colonial Women's Writing. 1986. Print.

Premnath, Gautam. 'Arguments with Nationalism in the Fiction of the Indian Diaspora'. Diss., Brown University, 2003. Print. 
Rakhee, Moral. 'The Postcolonial Writing on The Glass Palace' 2003: 151-152. Print.

Ravi, P.S. Modern Indian Fiction: History, Politics and Individual in the Novels of salman Rushdie, Amitav Ghosh and Upamanyu Chatterjee New Delhi: Prestige Books, 2003. Print.

'Ray Satyajit' in Tabish Khair (ed.) Amitav Ghosh: A Critical - Companion New Delhi: Permanent Black, 2003: 108. Print

Shammas, Anton. 'The Once and Future Egypt: Review of In An Antique Land'. New York Times Book Review. (1 August 1993). Sec.VII. 26. Print.

Sircar, Arjya. 'The Stranger Within: Amitav Ghosh's Quest for Identity'. Language Forum. 18.1-2 (1992): 143-47. Print.

Skinner, John. 'Embodying voices: Language and Representationin Amitav Ghosh's The Glass Palace'. BELL: Beligian Essay. On Language and Literature (2002): 137-49. Print.

Soueif, Ahdaf. 'Intimately Egyptian: Review of In An Antique Land'. Times Literary Supplement. (15 January 1993): 7. Print.

Srivastava, Neelam. 'Amitav Ghosh's Ethnographic Fictions: Intertextual Links between In an Antique Land and His Doctoral Thesis'. Journal lof Commonwealth Litrature. 36.2 (2001): 4564. Print.

Stageman, Mike. 'Innocence Lost: Indo-Anglian Representations of Post-Colonial Identies through Adoliscent Hardships'. Diss, 2001. Print.

Tadie, A. 'Amitav Ghosh: The Nuances of History'. Esprit (Paris)1 (2002): 62-73. Print.

'The Novels of Amitav Ghosh'. London Magazine. 37.3-4 (1997): 159-61.

'The Politics of Isolation and Resurgence in Dancing in Cambodia at Large in Burma' in R.K.Dhawan (ed.) The Novels of Amitav Ghosh: 282-94.

Thieme, J. 'The Discoverer Discovered: Amitav Ghosh's The Glass Palace,' in The Literature of Indian Diaspora: Essays in Criticism, ed by A.L. M.cLeod, New Delhi: Sterling Publishers, 2000. Print.

Tiwari, Shubha. Amitav Ghosh: A Cirtical Study New Delhi: Atlantic Publishers, 2003. Print.

'Travelling in the West: The Writing of Amitav Ghosh' in Tabish khair (ed.) Amitav Ghosh: A Critical Companion Delhi: Permanent Black, 2003: 9-35.Print.

Trikha, Pradeep. 'In An Antique Land: A Traveller's Tale' in R.K.Dhawan (ed.) The Novels of Amitav Ghosh. New Delhi: Prestige, 1999: 187-91.Print.

Tripathi, salil. 'The Past is Now: Review of Dancing in Cambodia, At Large in Barma'. Far Eastern Economic Review. 61.31 (30 July 1998): 42-43. Print.

Vinoda. T "Reflections on the Crystal Palace: The Glass Palace as a Post Colonialist Text". Kakatiya Journal of English Studies. Volume 22. . 2002. Print.

Wassef, Hind. 'Beyond the Divide: History and National Boundaries in the Work of Amitav Ghosh'. Alif: Journal of Comparative Poetics. 18 (1998): 75-95. Print.

Weisbord, Merrily. 'Amitav Ghosh; College English Review' 1.4 (1997): 4-5. Print.

Young, Robert J.C. Postcolonialism: A Very Short Introduction New York: Oxford UP, 2003. Print.

Zinkin, Taya. 'Review of Dancing in Cambodia, At Large in Burma'. Asian Affairs. 30.2 (1999): 23031. Print.

\section{AUTHOR's BIOGRAPHY}

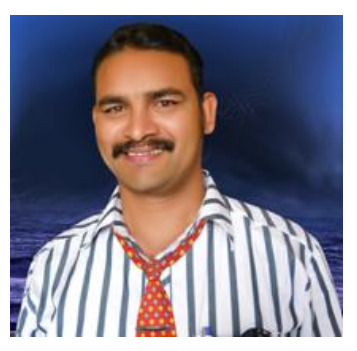

Dr.Venkateswarlu Yesapogu awarded his $\mathrm{PhD}$ degree in (2012) in the contemporary Indian fiction at the Acharya Nagarjuna University, GUNTUR, Andhra Pradesh, India, his M.A., M.Phil, also happened in the English literature. He is now teaching English Literature and Phonetics in V.V. \&M. Degree College. He became the youngest Principal FAC by virtue of seniority among existing staff since 2009. His teaching is on main research interests including teaching of Phonetic Science as well as communication skills. He has recently published two books. The first entitled "The Fictional World of Amitav Ghosh" with ISBN 9789382186397; the second entitled "The Feminist Perspective in Amitav Ghosh's Oeuvre" and published several other articles in reputed international journals. He has participated National and International seminars/conferences. 